\title{
INTERNATIONAL CONGRESSES OF INTEREST TO BIORHEOLOGISTS
}

\author{
1972 Perspectives in Biomedical Engineering
}

AN International Conference was held at the University of Strathclyde, Glasgow, Scotland on the 19 and 20 of June 1972, in conjunction with the Biological Engineering Society, to commemorate the tenth annivessary of the unit and the official opening of the unit's new building of $30,000 \mathrm{ft}^{2}$ floor area, donated by the Wolfson Foundation.

In the Symposium recent advances and perspectives in the unit's main areas of activity were discussed by speakers drawn from many countries, principally the U.K. and U.S.A.

There were four sessions:

Biochemical engineering. Biomaterials, haemorheology, cardiac assist devices, heart replacement, haemodialysis, microcapsular absorbants.

Biomechanics. Human spine and joints, body and externally powered prostheses and orthoses.

Tissue mechanics. Load deformation behaviour of bone, articular cartilage and soft tissue, multi-component materials.

Clinical measurement and data analysis. Ultrasonics, kinetography, ballistography, labour monitoring, data processing and computer display techniques.

Details may be obtained from Professor R. M. Kenedr, University of Strathclyde, BioEngineering Unit, Wolfson Centre, 106 Rottenrow, Glasgow G4 0NW.

(The Proceedings are being published by the Macmillan Co. in London.)

1973 The 10th Conference of The International Federation for Medical and Biological Engineering Will be held from 6 to 10 August 1973 in Dresden (German Democratic Republic)

The scientific programme will be divided into plenary sessions, on topics of general interest, and parallel sessions on special topics.

Proposed subjects for plenary sessions include experience and trends in screening, cybernetics, information content of medical and biological data, and automatic trend analysis in patient monitoring.

The Congress is to be combined with a large scientific and commercial exhibition, which will include equipment for use in biometry, patient monitoring, medical data processing, electro-medicine (electrotherapy), nuclear medicine, ultrasonics and thermography. It is planned that implantable and extra-corporeal systems, bio-chemical laboratory instruments and automatic analysers will also be on show.

For more details contact the Secretary DiPL.-ING. J. MATAUSCHEK, GDR-8030 Dresden, Postschliessfach 29, East Germany.

IVth International Congress on Thrombosis and Haemostasis

Sponsored by the International Society on Thrombosis and Haemostasis and the Scientific Council on Thrombosis of the International Society of Cardiology 19-22 June 1973, Vienna, Austria 